can be used safely in moderation for cattle, dairy cows and sheep; but they are not suitable for young stock, horses or pigs. Cooked potatoes, however, can be successfully fed to pigs of all ages, and a table of suitable quantities is provided. Potato and potato and green fodder silage are other useful ways of utilizing waste tubers, particularly if some of them are slightly diseased, and simple methods for preserving them in this way are described. Nutritious food of a feeding value equivalent to about a quarter of its weight of barley meal, and suitable for sheep, cattle and pigs, can thus be produced.

\section{Johann Friedrich Blumenbach (1752-1840)}

JohanN Friedrich Blumenbach, a pioneer in anthropology and eraniology, was born on May 11, 1752, at Gotha. He studied medicine at Jena under Soemmering and qualified in 1776 at Göttingen, where he was appointed extraordinary professor of the practice of medicine in the following year and full professor in 1778. In his thesis entitled "De generis humani varietate nativa" (1776), which according to Garrison is the starting point of modern ethnology, he based his classification of mankind upon the shape of the skull and the facial configuration as well as on the colour of the skin. As the result of his eraniological investigations, he divided the human race into five great families : the Caucasian or white race, the Mongolian or yellow, the Malayan or brown, the Negro or black, and the American or red.

Blumenbach was a voluminous writer. His principal work, which was published in 1790-1820, was entitled "Decades 1-6 collectiones suae craniorum diversarum gentium illustratæ". He was also the author of "Handbuch der Naturgeschichte" (177980), "Ueber der Bildungstrieb und das Zeugungsgeschäft" (1781), "Institutiones physiologicæ" (1787), "Beiträge zur Naturgeschichte" (1790-1811), and "Handbuch der vergleichenden Anatomie" (1805). He was also the editor of "Medicinische Bibliothek" from 1785 until 1795, and contributed many articles to periodical literature. He was a fellow of the Royal Society, member of the Royal Academy of Seiences of Paris, and the recipient of many other honours at home and abroad. He died on January 18, 1840.

\section{Neanderthal Man in Central Asia}

A PRELIMINARY account of the discovery of skeletal remains of Neanderthal man in Central Asia is given by Dr. Aleš Hrdlička through the Smithsonian Institution of Washington. The remains-the skull of a child, with the lower jaw and all the teeth, and some of the bones of the skeleton in a fragmentary state-were found by Dr. A. Nokladnikov in a cave of the Gissar Mountains of Siberia. The discovery is of special importance, as not only is this the first example of Neanderthal man to be recorded from Central Asia, but it is also the farthest extension of the type eastward hitherto known. With the exception of the finds in Palestine, all previous specimens have been found in Europe. Dr. Hrdlička, who has had an opportunity of examining the material while on a visit to Siberia recently, regards it as one of the most important discoveries in anthropology of the last two decades, and further as lending support to his view that there is an overlap in skull pattern between Sinanthropus and Neanderthal man.

In an account of the find which Dr. Hrdlička received at first hand from those who were responsible for the discovery, it was stated that the cave deposits contained many splintered bones of deer, leopards, wild horses, goats, boars, marmots and birds. Many of these showed evidence of having been used in the manufacture of stone implements. Most of these implements were made of local limestone, but the finest were of jasper. Good material for implementmaking, however, was scarce. Typical Mousterian scrapers and small pointed implements, chipped on one side, were associated with the animal bones, and both were in relation to fire-places. The human skeletal remains were imbedded in a sterile underlying stratum. An interesting feature of their disposal was that they were encircled by five pairs of goat horns, of which three were still united.

\section{Psychology of the Initiate}

An interesting sidelight is thrown on certain changes in mentality taking place after initiation by an examination of two series of drawings made by an Australian aboriginal boy, which have been recorded and reproduced by C. P. Mountford, acting ethnologist of the South Australian Museum (Records S. Austral. Mus., 6, 2 ; 1939). The subject was one of two interpreters accompanying an anthropological expedition of the University of Adelaide to the Warburton Ranges of Western Australia in 1935. At the time of his engagement it was understood that he was a full initiate ; but when an investigation of aboriginal art was being made, it was noted that when drawings of a secret character were being made by tribesmen, they were carefully concealed on his approach. His own drawings in the first series invariably represented objects of, or known to, European civilization.

This fact, coupled with his failure as an interpreter, led to inquiry, when it was found that initiation of the man had not been completed. 'Though circumcized, he had not been subincized, and consequently in all matters affecting tribal ritual he was virtually ostracized, while his behaviour consorted with that of younger members of the tribe. Full initiation, which was then carried out, induced a remarkable change in his outlook, behaviour, and what from one point of view was of greater moment, in the attitude of other members of the group. The youth assumed the attitude and behaviour of a senior of the tribe; he was no longer prevented from seeing cerernonial drawings and taking part in ritualistic discussions, while, it is interesting to note, his own drawings now depicted the ceremonial designs associated with, or recording tribal traditions. The author's comment is significant. He points out how any interference with tribal ritual by outside influence may prove an effectual bar to association with tribal society, while still not securing an admission to any real participation in white civilization. The lesson is instructive. 